\title{
EFEKTIVITAS SERBUK JANTUNG PISANG TERHADAP PRODUKSI ASI PADA IBU NIFAS
}

\author{
Hasanah Pratiwi Harahap, Winda Agustina, Ainun Mardhiah \\ Prodi D4 Kebidanan, Fakultas Farmasi dan Kesehatan, Institut Kesehatan Helvetia \\ Jl. Kapten Sumarsono No.107 A Medan \\ Email: hasanah.hrp@gmail.com, windaagustina@helvetia.ac.id, ainun.syamaun@gmail.com
}

\begin{abstract}
Kata Kunci:
Jantung Pisang, ASI

ABSTRAK

Proses pembentukan ASI melibatkan gabungan dari hormon prolaktin dan oksitosin serta adanya refleks berupa hisapan bayi pada putting ibu. Pencapaian ASI ekslusif di Asahan sebesar 43,6\%. Kegagalan pemberian ASI dapat memberikan dampak infeksi bayi dan serta meningkatkan kanker payudara pada ibu. Penelitian ini bertujuan untuk mengetahui efektivitas serbuk jantung pisang terhadap produksi ASI. Jenis penelitian kuantitatif dengan metode pre eksperimental design dengan desain posttest control group design. Lokasi penelitian di Kelurahan Binjai Serbangan, Kecamatan Air Joman mulai Agustus 2020-Juni 2021 dengan tekhnik purposive sampling dan perbandingan 1:1 sebanyak 26 orang terdiri kelompok intervensi dan kontrol. Intervensi diberikan serbuk jantung pisang dan penilaian menggunakan kuesioner kriteria kelancaran produksi ASI yang terbagi indikator bayi dan ibu. Penilaian dilakukan sebanyak 4 tahap. Analisis data yang digunakan adalah independent sample t test dengan tingkat kemaknaan 95\% $(0,05)$. Hasil penelitian diperoleh nilai sig 0,031 dengan mean kelompok intervensi 19,08 dan kontrol 16,08 pada indikator bayi, sementara produksi ASI dari indikator ibu nilai sig.0,006 dengan mean sebesar 22,77 untuk kelompok intervensi dan 17,85 untuk kontrol. Kesimpulan ada efektivitas berupa peningkatan produksi ASI dari indikator bayi dan ibu dengan pemberian serbuk jantung pisang. Diharapkan tenaga kesehatan khususnya di fasilitas primer dan klinik untuk membantu dan memberikan penkes ibu nifas dalam meningkatkan produksi ASInya dengan memberdayakan hasil alam.
\end{abstract}

Keywords:

Banana Heart, Breast Milk

Info Artikel

Tanggal dikirim: 6-9-2021

Tanggal direvisi:22-9-2021

Tanggal diterima:23-1-2022

DOI Artikel:

10.36341/jomis.v6i1.2092

Creative Commons

Attribution-NonCommercialShareAlike 4.0 International $\underline{\text { License. }}$

\section{ABSTRACT}

The process of forming breast milk involves a combination of the hormones prolactin and oxytocin and a reflex in the form of sucking the baby on the mother's nipple. The achievement of exclusive breastfeeding in Asahan is 43.6\%. Failure to breastfeed can have an impact on infant infection and increase breast cancer in the mother. This study aims to determine the effectiveness of banana bud powder on breast milk production. This type of research is quantitative with a pre-experimental design method with a posttest control group design. The research location is in the Binjai Serbangan Village, Air Joman District from August 2020-June 2021 with a purposive sampling technique and a 1:1 ratio of 26 people consisting of the intervention and control groups. The intervention was given banana flower powder and the assessment used a criteria questionnaire for the smoothness of breast milk production which was divided into indicators for infants and mothers. The assessment is carried out in 4 stages. Data analysis used was independent sample t test with a significance level of $95 \%$ (0.05). The results of the study obtained a sig value of 0.031 with a mean of 19.08 for the intervention group and 16.08 for the control group on the infant indicator, while the milk production from the mother's indicator was sig.0.006 with a mean of 22.77 for the intervention group and 17.85 for the control group. The conclusion is that there is an effectiveness in the form of increasing breast milk production from the indicators of infants and mothers by giving banana flower powder. It is expected that health workers, especially in primary facilities and clinics, will assist and provide health education for postpartum mothers in increasing their milk production by empowering natural products. 


\section{PENDAHULUAN}

Air Susu Ibu (ASI) dihasilkan karena aktivitas gabungan antara sistem hormon dan refleks hisap bayi yaitu dengan adanya hormon prolaktin dan oksitosin. Selama kehamilan hormon prolaktin akan meningkat namun ASI belum keluar karena masih terhalang oleh tingginya hormon estrogen dan pada saat persalinan hormon estrogen dan progesteron akan berkurang dan menyebabkan produksi hormon prolaktin akan lebih tinggi dan ditambah juga karena adanya gerakan isapan bayi yang merangsang serat saraf di areola sehingga terjadi keluarnya ASI [1].

ASI adalah makanan utama yang dibutuhkan untuk bayi baru lahir 0-6 bulan. Prevalensi pemberian ASI ekslusif di dunia sekitar $38 \%$ dan kegagalan ibu untuk memberikan ASI sekitar 10-15\%, sedangkan di Indonesia hanya sekitar 9 dari 10 ibu yang telah memberikan ASI, namun penelitian IDAI menemukan bahwa hanya $49,8 \%$ yang memberikan menyusui selektif selama setengah tahun [2]. Berdasarkan informasi dari Profil Dinas Kesehatan Provinsi Sumatera Utara tahun 2017, telah sampai pada target publik $>40 \%$. Rezim/Kota dengan pencapaian $>40 \%$ termasuk Asahan [3].

Kegagalan pemberian ASI eksklusif menyebabkan terhentinya pemberian ASI dan pengenalan dini penggunaan susu formula pada bayi [4]. Kegagalan ini meningkatkan kejadian infeksi seperti otitis media, gastroenteritis, pneumonia, obesitas, diabetes tipe 1 dan tipe 2, leukemia dan sindrom kematian mendadak, serta kanker payudara ibu premenopause, kanker ovarium, penambahan berat badan, dan sindrom metabolik [5].

Salah satu upaya untuk meningkatkan produksi ASI adalah dengan mengonsumsi makanan yang dapat memengaruhi produksi ASI. Masyarakat Indonesia memiliki tradisi atau kebiasaan memanfaatkan potensi alam, baik tumbuhan maupun hewan, sebagai bahan penyembuhan. Tumbuhan maupun hewan cukup diminati sebagai terapi alternatif pengobatan karena memiliki efek samping lebih sedikit dan harganya juga yang lebih murah [6]. Produksi ASI dapat diupayakan dengan adanya tambahan makanan bergizi yang dapat diperoleh dari keanekaragaman hayati [7], berupa jantung pisang dan daun pepaya. Jantung pisang memiliki kandungan zat laktagogum seperti alkaloid, polifenol, steroid, flavonoid dan substansi lainnya dalam menstimulasi hormon oksitosin dan prolaktin untuk meningkatkan dan memperlancar produksi ASI. Selain itu terdapat vitamin A, vitamin B1 dan vitamin C serta beberapa mineral penting yang dibutuhkan oleh tubuh, antara lain zat besi, kalsium dan fosfor [8].

Hasil wawancara pada 13 orang ibu nifas yang menyusui diperoleh 7 orang diantaranya memilih meminum obat (asifit) yang diberikan oleh petugas kesehatan, 4 orang dengan mengkosumsi olahan sayur daun katuk, 2 orang lainnya dengan memakan olahan jantung pisang dalam bentuk sayur tumisan. Tujuan penelitian khusus menganalisis efektivitas pemberian serbuk jantung pisang pada ibu nifas di Kelurahan Binjai Serbangan Kecamatan Air Joman.

\section{TINJAUAN PUSTAKA Masa Nifas}

Masa nifas adalah masa setelah berakhirnya persalinan dan berakhir setelah kurang lebih 6 minggu. Istilah kehamilan mengacu pada periode 6 minggu yang berlangsung dari akhir persalinan sampai organ reproduksi wanita kembali ke keadaan sebelum hamil [9]. Masa nifas memberikan dampak pada sistem hormonal. Perubahan sistem hormonal yang terjadi pada masa nifas ditandai dengan produksi hormon prolaktin dan oksitosin. Menghilangnya pengaruh penekanan dari esterogen dan progesteron terhadap hipofisis, menyebabkan kadar estrogen dan progesteron akan menurun pada saat hari kedua atau ketiga pasca persalinan. Hal ini menimbulkan pengaruh hormonhormon hipofisis kembali, antara lain lactogenic hormon. Lactogenic hormon menghasilkan hormon prolaktin sehingga terjadi sekresi ASI [10], [11]. Hormon oksitosin yang disekresikan oleh kelenjar 
pituitari bekerja pada otot-otot rahim dan jaringan payudara. Selama kala III persalinan, hormon oksitosin berperan melepaskan plasenta dan mempertahankan kontraksi, sehingga mencegah perdarahan. Menyusui dapat merangsang produksi ASI dan melepaskan oksitosin untuk mendorong pertumbuhan rahim [12].

\section{ASI (Air Susu Ibu)}

Air Susu Ibu (ASI) adalah cairan yang terdiri dari campuran dua zat, yaitu lemak dan air dalam larutan protein, laktosa dan garam anorganik yang dihasilkan oleh kelenjar susu ibu dan digunakan sebagai makanan bayi [13].

\section{Pengeluaran ASI}

Laktasi mempunyai dua pengertian yaitu:

1. Produksi susu (refleks prolaktin): Penurunan kadar estrogen meningkatkan kadar prolaktin dan memulai produksi susu. Produksi prolaktin yang berkelanjutan disebabkan oleh bayi yang menyusui.

2. Pengeluaran ASI (refleks letdown/pelepasan ASI): Proses laktasi atau yang biasa dikenal dengan "refleks letdown" berada di bawah kendali sistem neuroendokrin, dimana bayi yang menyusu payudara ibu akan merangsang produksi oksitosin sehingga menyebabkan penyusutan sel-sel epitel. Kontraksi sel-sel ini akan memaksa susu yang dikeluarkan dari alveolus ke dalam sistem saluran susu dan kemudian mengalir melalui saluran susu ke dalam mulut bayi sehingga ASI tersedia untuk bayi [13].

\section{Kriteria Kelancaran Produksi ASI} Indikator Ibu

1. Permulaan pengeluaran ASI

2. Frekuensi menyusui

3. Kepuasaan Ibu

4. Ibu relax (tampak tenang saat menyusui)

\section{Indikator Bayi}

1. Berat badan bayi

2. BAK dan BAB bayi

3. Jumlah jam tidur bayi [14].
Jantung pisang (musa paradisiaca normalis) adalah sisa bunga pisang yang sudah tidak berbuah lagi. Bagian ini harus dipotong agar pisang dapat tumbuh dengan optimal, sehingga jantung pisang tidak terbuang dan dibuang begitu saja. Jantung pisang juga rasanya tidak enak, sehingga harganya murah [15]. Jantung pisang merupakan tanaman yang mengandung laktagogum, yang memiliki kemampuan untuk merangsang hormon oksitosin dan prolaktin seperti alkaloid, polifenol, steroid, flavonoid dan zat lain yang meningkatkan dan memperlancar produksi ASI, vitamin A, vitamin B1 dan vitamin C. Beberapa mineral penting yang dibutuhkan tubuh, antara lain zat besi, kalsium dan fosfor. Setiap 25 gram jantung pisang mengandung 7,1 gram karbohidrat, 31 kkal kalori, 0,3 gram lemak dan 1,2 gram senyawa protein [16].

Pembuatan serbuk jantung pisang dimulai dengan: (1) pemilihan jantung pisang jenis kepok kuning berwarna merah keunguan, tidak berlubang dan bebas hama (2) pemotongan menjadi 2 bagian untuk memudahkan perebusan (3) pencucian dengan air mengalir dan ditiriskan (4) blancing dengan air yang sudah mendidih selama 2 menit (5) pengirisan jantung pisang (6) pengeringan dengan oven suhu $50^{\circ} \mathrm{C}$ selama 12 jam (7) pengambilan serbuk dengan diblender dan diayak menggunakan mesh 60 .

Berdasarkan penelitian Rilyani dan Renda Wulandasari (2019) menunjukkan ada perbedaaan rata-rata ASI ibu sebelum sebesar 4,90 dan sesudah 7,37 pemberian sayur jantung pisang dengan nilai p-value 0.000 [17]. Hasil penelitian Apriza (2017) diperoleh nilai $\mathrm{p}$ value 0,001 , maka dapat disimpulkan ada pengaruh konsumsi rebusan jantung pisang terhadap ekskresi ASI pada ibu menyusui [18].

\section{METODE}

Desain penelitian menggunakan pre eksperimental design dengan desain posttest control group design. Kelompok intervensi mendapat perlakuan sekali sehari selama 4 hari berturut-turut. Penelitian ini dilakukan di 
LK II, IV dan V, Desa Binjai Serbangan, Kecamatan Air Joman, dimulai dengan pengajuan proposal hibah PDP LLDIKTI pada bulan Agustus 2020 untuk penelitian yang akan dilakukan pada bulan Juni 2021. Populasi penelitian ini sebanyak 26 ibu nifas yang menyusui menggunakan tekhnik purposive sampling. Perbandingan 1:1, dimana 13 responden mengkonsumsi serbuk jantung pepaya dan 13 responden pada kelompok kontrol. Kriteria inklusi adalah ibu bersedia menjadi responden, ibu nifas yang aktif menyusui, ibu paritas satu dan tidak memiliki masalah payudara.

Pemberian intervensi pada kelompok dengan memberikan 2 gr serbuk jantung pisang dicampur dengan $7 \mathrm{gr}$ gula dan $100 \mathrm{ml}$ air hangat lalu diminum oleh ibu 1 kali sehari yaitu pada jam 08.00 wib selama 4 hari. Perubahan produksi ASI dinilai menggunakan kuesioner kriteria kelancaran produksi ASI dengan indikator bayi 6 poin dan indikator ibu 10 poin pertanyaan yang dilakukan melalui 4 tahap posttest dilakukan 4 kali setelah sehari dilakukan intervensi. Kuesioner produksi ASI didasarkan pada penelitian Budiati [14]. Pengumpulan data penelitian dengan kerjasama 2 bidan desa yang bekerja di lokasi penelitian. Uji statistik yang digunakan adalah independent sample t-test dengan taraf signifikansi $95 \% \quad(0,05)$. Penelitian ini mendapat persetujuan etik dari Komite Etik Penelitian Kedokteran Universitas Prima Indonesia dengan nomor 004/KEPK/UNPRI/V/2021.

\section{HASIL DAN PEMBAHASAN \\ 1. Karakteristik Responden}

Responden dalam penelitian ini berjumlah 26 ibu nifas dengan umur terbanyak 11 orang $(42,3 \%)$ pada kelompok 23-27 tahun, pendidikan terbanyak pada SMP 9 orang $(34,6 \%)$ dan terbanyak tidak bekerja yaitu 18 orang $(69,2 \%)$. Hasil ini dapat dilihat pada tabel karakteristik responden berikut :

Tabel 1. Karakteristik Responden

\begin{tabular}{llcc}
\hline Karakteristik & Kategori & Frekuensi & Persentase \\
\hline Umur & 18-22 tahun & 7 & 26,9 \\
& 23-27 tahun & 11 & 42,3 \\
& 28-32 tahun & 8 & 30,8 \\
\hline Pendidikan & Tidak tamat SD & 3 & 11,5 \\
& SD & 7 & 26,9 \\
& SMP & 9 & 34,6 \\
& SMA & 4 & 15,4 \\
& PT & 3 & 11,5 \\
\hline Pekerjaan & Bekerja & 8 & 30,8 \\
& Tidak bekerja & 18 & 69,2 \\
\hline
\end{tabular}

Sumber : Data Primer, 2021

\section{Analisis Bivariat}

Data yang diperoleh merupakan data primer dan berskala interval, sehingga dilakukan analisis kuantitatif dengan menggunakan uji statistik parametrik (independent sample $t$ test) dengan hasil sebagai berikut:

\section{1) Uji Persayaratan}

Uji Persyaratan sebelum analisis independent sample $t$ test dilaksanakan, terlebih dahulu dilakukan uji normalitas data dan uji homogenitas data. Adapun uji normalitas dan homogenitas sebagai berikut:

\section{a. Uji Normalitas}

Uji normalitas dilakukan untuk mengetahui normal tidaknya distribusi data yang akan dianalisis. Berdasarkan tabel 2 diperoleh bahwa pada indikator bayi kelompok serbuk jantung pisang 0,400, dan kelompok kontrol 0,060. Pada indikator ibu 
serbuk jantung pisang 0,199 dan kelompok kontrol 0,285. Semua nilai sig.tersebut $>0,05$, yang berarti data berdistribusi normal.

Tabel 2. Hasil Uji Normalitas Data

\begin{tabular}{lllcl}
\hline Indikator & Kelompok & \multicolumn{3}{c}{ Shapiro-Wilk } \\
\cline { 3 - 5 } Produksi ASI & & Statistik & Df & Sig. \\
\hline Bayi & Serbuk jantung pisang & 0,935 & 13 & 0,400 \\
& Kontrol & 0,874 & 13 & 0,060 \\
\hline Ibu & Serbuk jantung pisang & 0,913 & 13 & 0,199 \\
& Kontrol & 0,924 & 13 & 0,285 \\
\hline
\end{tabular}

Sumber : Data Primer, 2021

\section{b. Uji Homogenitas}

Penelitian ini menggunakan uji Levene untuk uji homogenitas yang diperoleh pada tabel 3 terdiri dari indikator produksi
ASI bayi nilai sig. 0,279 dan ibu nilai sig. $0,479>0,05$ menunjukkan semua data (serbuk jantung pisang dan kontrol) adalah homogen.

Tabel 3. Hasil Uji Homogenitas Data

\begin{tabular}{llll}
\hline Indikator Produksi ASI & Levene Statistic & Df & Sig. \\
\hline Bayi & 1,220 & 24 & 0,279 \\
\hline Ibu & 0,517 & 24 & 0,479 \\
\hline
\end{tabular}

Sumber : Data Primer, 2021

\section{2) Uji Hipotesis}

Hasil tabel 4. diperoleh nilai rata-rata produksi ASI dari indikator bayi pada kelompok serbuk jantung pisang sebesar 19,08 dan kontrol 16,08, sementara produksi ASI dari indikator ibu sebesar 22,77 untuk kelompok serbuk jantung pisang dan 17,85 untuk kelompok kontrol. Nilai selisih rata-rata produksi ASI dari indikator bayi pada kelompok serbuk jantung pisang dan kontrol adalah 3,000 dan selisih perbedaan tersebut adalah 0,306 - 5,694, sedangkan nilai selisih rata-rata produksi ASI dari indikator ibu 4,923 dengan perbedaan selisih sebesar 1,561 - 8,285. Berdasarkan nilai sig. 0,031 menunjukkan terdapat perbedaan rata-rata produksi ASI pada indikator bayi begitu juga produksi ASI pada indikator ibu menunjukkan ada perbedaan yang signifikan kelompok serbuk jantung pisang dengan kelompok kontrol sebesar 0,006.

Tabel 4. Hasil Uji Hipotesis dengan Independent Sample T Test

\begin{tabular}{llllll}
\hline $\begin{array}{l}\text { Indikator } \\
\text { Produksi } \\
\text { ASI }\end{array}$ & Kelompok & Mean & $\begin{array}{l}\text { Mean } \\
\text { Difference }\end{array}$ & 95\% CI & Sig. \\
\hline Bayi & Serbuk jantung pisang & 19,08 & 3,000 & $0,306-5,694$ & 0,031 \\
& Kontrol & 16,08 & & & \\
\hline Ibu & Serbuk jantung pisang & 22,77 & 4,923 & $1,561-8,285$ & 0,006 \\
& Kontrol & 17,85 & & & \\
\hline
\end{tabular}




\section{Produksi ASI Berdasarkan Indikator Bayi}

Hasil uji statistik dengan independent sample $t$ test diperoleh nilai sig. 0,031 yang berarti menunjukkan ada perbedaan efektivitas yaitu terjadi peningkatan produksi ASI dari indikator bayi dengan pemberian serbuk jantung pisang dan kelompok kontrol pada ibu nifas di Kelurahan Binjai Serbangan. Hasil penelitian ini juga sejalan dengan penelitian Riyani dan Renda tentang konsumsi sayur jantung pisang terhadap produksi ASI pada indikator kecukupan ASI dan menggunakan uji dependen $t$ tes diperoleh nilai sig. $0,000<0,05$ yang berarti ada pengaruh konsumsi sayur jantung pisang dengan peningkatan produksi ASI pada ibu nifas [17]. Hal yang sama dilakukan oleh Sri dan Desri dengan pemberian rebusan jantung pisang untuk menilai produksi ASI berdasarkan indikator bayi dan gelas ukur (cc) terdiri dari 2 kelompok serta menggunakan uji independen sample $t$ tes diperoleh nilai $\mathrm{p} 0,01$ yang menunjukkan ada perbedaan produksi ASI dari kedua kelompok tersebut [19]. Hasil yang sejalan dengan penelitian Indah dan Umi diperoleh ada peningkatan skor $>4$ dari 7 indikator produksi ASI yang dinilai dari karakteristik bayi sebelum dan setelah pemberian olahan jantung pisang pada ibu nifas di PMB Siti Isti'anatul Amd,Keb [20].

ASI adalah suatu emulsi lemak dalam larutan protein, laktosa dan garam organik yang disekresikan oleh kedua kelenjar susu dan merupakan makanan utama bayi [21]. Hisapan bayi memeengaruhi produksi ASI karena saat bayi menyusu dari payudara, ada rangsangan saraf pada puting dan areola ibu. Rangsangan ini diteruskan ke kelenjar hipofisis melalui nervus vagus, kemudian ke lobus anterior. Lobus ini mengeluarkan hormon prolaktin, yang memasuki aliran darah dan mencapai kelenjar untuk menghasilkan susu. Kelenjar ini akan dirangsang untuk memproduksi ASI. Hormon prolaktin yang berperan dalam produksi ASI [22].

Laktagogum merupakan obat yang dapat meningkatkan atau memperlancar produksi ASI. Laktagogum memiliki fungsi untuk merangsang pengeluaran hormon oksitosin dan prolaktin seperti alkaloid, polifenol, steroid dan flavonoid yang efektif dalam meningkatkan sekresi ASI. Mekanisme kerja laktagogam yang membantu merangsang laktasi adalah dengan secara langsung merangsang aktivitas protoplasma sel-sel sekretori kelenjar susu, merangsang ujung saraf sekretori kelenjar susu untuk meningkatkan laktasi atau dengan merangsang hormon. Prolaktin, hormon perangsang kelenjar susu ke kelenjar susu sel epitel alveolar yang merangsang laktasi [23].

Jantung pisang mengandung zat laktagogum seperti alkaloid, polifenol, steroid, flavonoid dan zat lain yang merangsang hormon oksitosin dan prolaktin untuk meningkatkan dan memperlancar produksi ASI dan juga terdapat vitamin A, vitamin B1 dan vitamin C serta beberapa mineral penting yang dibutuhkan oleh tubuh, antara lain zat besi, kalsium dan fosfor [8]. Kandungan zat laktogogum yang berkhasiat terhadap peningkatan sekresi air susu mempunyai bahan aktif yang bekerja seperti Prolactin Releasing Hormon (PRH), yang mengandung bahan aktif senyawa steroid seperti prolaktin dan mengandung bahan aktif yang berkhasiat seperti oksitosin [24].

Menurut Budiati (2009) Produksi ASI ini didasarkan pada indikator bayi yaitu frekuensi buang air kecil, dimana bayi yang cukup produksi ASInya maka selama 24 jam paling sedikit akan BAK 6 kali, warna urin kuning jernih, jika ASI cukup setelah menyusu maka bayi tertidur/tenang selama 23 jam [14]. Indikator lain adalah karakteristik BAB bayi, pada 24 jam pertama bayi mengeluarkan $\mathrm{BAB}$ yang berwarna hijau pekat, kental dan lengket atau mekonium, BAB ini berasal dari saluran pencernaan bayi serta cairan amnion [25]. Pola eliminasi tergantung intake yang bayi dapatkan. Bayi yang hanya meminum ASI, umumnya pola BABnya 2-5 kali sehari dengan warna kuning keemasan, tidak terlalu encer dan tidak terlalu pekat [26]. Frekuensi serta karkateristik BAK dan $\mathrm{BAB}$ ini juga dipengaruhi oleh frekuensi ibu menyusui bayinya, semakin sering 
menyusui bayi menyebabkan bayi lebih sering $\mathrm{BAB}$, sehingga bilirubin yang terdapat pada bayi di hari pertama kehidupannya dapat dibuang melalui feses yang berwarna kehijauan (mekonium). Jika frekuensi BABnya kurang, maka bilirubin akan diserap kedalam usus. Dikarenakan kolostrum bersifat sebagai laksatif sehingga bilirubin yang terdapat dalam usus dapat dikeluarkan daripada diserap kembali. Oleh karena itu, menyusui dengan lebih sering merupakan cara terbaik untuk mencegah terjadinya hiperbilirumia (jaundice) pada bayi [25].

Jantung pisang dapat diolah dalam beberapa bentuk, seperti olahan menjadi serbuk jantung pisang. Pada penelitian ini serbuk jantung pisang diolah dari jantung pisang kepok dan segar yang dikeringkan lalu diminum sebanyak 1 hari sekali dengan tambahan gula dan air hangat. Perlakuan ini diberikan pada ibu nifas selama 4 hari dan diperoleh terdapat pengaruh berupa peningkatan produksi ASI pada ibu nifas setelah pemberian serbuk jantung pisang dengan nilai rata-rata 19,08 daripada kelompok kontrol yang tidak diberikan intervensi sebesar 16,08. Adanya perubahan yang dialami oleh bayi setelah ibu mengkonsumsi serbuk jantung pisang ini, meningkatnya frekuensi menyusui berarti produksi ASI meningkat dan adanya perubahan pola eliminasi BAK dan BAB yang lebih teratur hingga normal. Perubahan ini dialami bayi ada yang sejak hari pertama hingga hari ketiga intervensi.

Menurut analisis peneliti terhadap 13 responden, peningkatan ASI dipengaruhi oleh makanan yang mengandung gizi, dan mengandung senyawa kimia yang dapat merangsang produksi ASI yaitu senyawa laktogagum. Pada penelitian ini 8 responden mengalami peningkatan yang signifikan pada hari pertama terjadi peningkatan 4-5 skor dari 6 indikator, sedangkan 5 responden lagi produksi ASI mengalami peningkatan dihari kedua dan ketiga setelah diberikan serbuk jantung pisang. Hal ini terjadi karena respon sistem pencernaan setiap bayi berbeda-beda yang diketahui sistem pencernaan bayi belum sempurna, terutama usus halus bayi yang baru lahir masih berbentuk seperti saringan pasir, pori-pori pada usus halus ini memudahkan masuknya protein atau bakteri secara langsung ke seluruh sistem peredaran darah dan dapat menyebabkan gangguan pencernaan berupa reaksi alergi menyesuaikan dengan intake yang diterima dari ibu. Respon inilah yang berpengaruh terhadap penilaian indikator produksi ASI. Kelompok kontrol perubahan bayi tidak begitu terlihat yang didasarkan hasil tidak terdapat perubahan eliminasi pada 12 bayinya, hanya 1 bayi yang mengalami perubahan dan terjadi pada hari ke-4 penilaian.

\section{Produksi ASI Berdasarkan Indikator Ibu}

Hasil uji statistik dengan independent sample $t$ test diperoleh nilai sig. 0,006 yang berarti menunjukkan ada perbedaan efektivitas yaitu peningkatan produksi ASI dari indikator ibu dengan pemberian serbuk jantung pisang dan kelompok kontrol pada ibu nifas di Kelurahan Binjai Serbangan. Hasil yang sama diperoleh Rice, Lidia dan Indah ada peningkatan produksi ASI dengan rata-rata $12 \mathrm{ml}$ setelah mengkonsumsi jantung pisang selama 3 hari dan nilai p 0,000 dengan uji dependen t test pada ibu nifas di Desa Sungai Putih [27]. Hal yang sama diperoleh Haryati terdapat nilai p 0,040 dengan uji paired $\mathrm{t}$ test menunjukkan ada pengaruh konsumsi sayur bening jantung pisang dengan peningkatan produksi ASI pada ibu menyusui di Desa Teluk Kambang Kabupaten Indragiri Hilir [28].

Masa nifas memberikan dampak pada sistem hormonal. Meningkatnya produksi hormon prolaktin dan oksitosin merupakan tanda perubahan sistem hormonal pada masa nifas. Hari kedua dan ketiga pasca persalinan akan terjadi kondisi hilangnya pengaruh estrogen dan progesteron terhadap hipofisis yang kemudian menimbulkan kembalinya respon positif seperti produksi lactogenic hormon. Lactogenic hormon menghasilkan hormon prolaktin sehingga terjadi sekresi ASI [10], [11]. Banyak faktor yang dapat 
mempengaruhi produksi ASI. Faktor yang paling berpengaruh adalah faktor endokrin yaitu hormon prolaktin dan oksitosin. Jika kedua hormon ini tidak diproduksi, akan sulit bagi ibu untuk memproduksi ASI yang kemudian membutuhkan tindakan khusus dalam pemberian air susu ibu pada bayi [29].

$$
\text { Jantung pisang mengandung }
$$

laktagogum. Laktagogum memiliki potensi dalam menstimulus hormon oksitoksin dan prolaktin seperti alkaloid, polifenol, steroid, palfonoid dan substansi lainnya yang paling efektif dalam meningkatkan dan memperlancar produksi ASI. [24].

Indikator penilaian produksi ASI dari ibu diantaranya adalah ketegangan payudara, let downrefleks bekerja dengan baik, yang menandakan kerja dari hormon oksitosin yang menyebabkan terjadanya let down reflek ini bekerja dengan baik. Ibu menyusui menggunakan kedua payudaranya dengan relax dan terlihat payudara yang tegang dan memerah karena ASI penuh tidak lecet serta bayi menyusui tanpak kuat dan tenang dengan frekuensi > 8 kali sehari [14].

Jantung pisang dapat diolah dalam beberapa bentuk, seperti olahan menjadi serbuk jantung pisang. Pada penelitian ini serbuk jantung pisang diolah dari jantung pisang kepok dan segar yang dikeringkan lalu diminum sebanyak 1 hari sekali dengan tambahan gula dan air hangat. Perlakuan ini diberikan pada ibu nifas selama 4 hari dan diperoleh terdapat pengaruh berupa peningkatan produksi ASI pada ibu nifas setelah pemberian serbuk jantung pisang dengan nilai rata-rata 19,08 daripada kelompok kontrol yang tidak diberikan intervensi sebesar 17,97. Adanya perubahan yang dialami oleh ibu setelah mengkonsumsi serbuk jantung pisang ini, yaitu meningkatnya produksi ASI meningkat dengan adanya perubahan dari payudara ibu yang selalu terasa tegang hingga ASI merembes dikarenakan penuh dan frekuensi menyusui bayi yang semakin sering. Menurut analisis peneliti terhadap 13 responden, terdapat 7 responden mengalami peningkatan yang signifikan pada hari pertama terjadi peningkatan 5-6 skor dari 10 indikator, sedangkan 6 responden lagi produksi ASI mengalami peningkatan dihari kedua dan ketiga setelah diberikan serbuk jantung pisang. Hal ini dapat dipengaruhi oleh usia responden dalam kategori produktif yaitu 2327 tahun, serta oleh status pekerjaan yang tidak bekerja, sehingga ibu tidak mengalami kelelahan dan kesibukan bekerja pada paritas primigravida, menyusui dan sedang masih dalam usia muda seperti lobus di payudara, dan faktor psikologis dan psikologis ibu menyusui memiliki pengaruh yang sangat besar terhadap proses menyusui dan peningkatan produksi ASI.

\section{KESIMPULAN}

Hasil penelitian diperoleh kesimpulan produksi ASI pada ibu nifas dari indikator bayi dan ibu diperoleh ada perbedaan efektivitas berupa peningkatan produksi ASI dengan pemberian serbuk jantung pisang

\section{DAFTAR PUSTAKA}

[1] R. Y. Astutik, Payudara dan laktasi. Jakarta: Salemba Medika, 2017.

[2] R. Oktova, "Determinan yang Berhubungan dengan Pemberian MPASI Dini pada Bayi Usia 0-6 Bulan," J. Kesehat., vol. 8, no. 1, pp. 84-90, 2017.

[3] Dinas Kesehatan Sumatera Utara, "Profil Kesehatan Sumatera Utara," Medan: Dinas Kesehatan Sumatera Utara, 2017.

[4] A. Sultana, K. U. R. Rahman, and S. Manjula, "Clinical Update and Treatment of Lactation Insufficiency," Med. J. Islam. World Acad. Sci., vol. 109, no. 555, pp. 1-10, 2013.

[5] M. I. Ikhlasiah and L. M. Winarni, "Pemberian Jus Daun Pepaya bagi Ibu Menyusui yang Bekerja terhadap Peningkatan Kadar Hormon Prolaktin dan Berat Badan Bayi di Tangerang," J. Kebidanan Malahayati, vol. 6, no. 1, pp. 89-94, 2020.

[6] I. P. Winata and A. D. Putri, "Biji Mahoni sebagai Antioksidan," $J$. 
Penelit. Perawat Prof., vol. 1, no. 1, pp. 89-94, 2019.

[7] T. Murtiana, "Pengaruh Konsumsi Daun Katuk dengan Peningkatan Produksi ASI pada Ibu Menyusui di Wilayah Puskesmas Sawah Lebar Kota Bengkulu Tahun 2011," [Skripsi]. Politeknik Kesehatan Bengkulu., 2011.

[8] H. Harismayanti, R. Febriyona, and M. Tuna, "Pengaruh Konsumsi Jantung Pisang terhadap Peningkatan Produksi ASI pada ibu Masa Nifas," in In prosiding seminar nasional 2018 "Peran dan Tanggung Jawab Tenaga Kesehatan dalam Mendukung Program Kesehatan Nasional, " 2019.

[9] T. Nugroho, "Buku Ajar Asuhan Kebidanan Nifas (Askeb 3)," Yogyakarta Nuha Med., 2014.

[10] A. Maryunani, Inisiasi Menyusu Dini, ASI Ekslusif dan Manajemen Laktasi. Jakarta: CV.Trans Info Media, 2015.

[11] R. Y. Astutik, Payudara dan Laktasi, Edisi 2. Jakarta: Salemba Medika, 2017.

[12] Direktorat Jenderal Kesehatan Masyarakat, Panduan Pelayanan Pasca Persalinan Bagi Ibu dan Bayi Baru Lahir. Jakarta: Kementerian Kesehatan RI, 2019.

[13] A. Maryunani, Asuhan pada Ibu dalam Masa Nifas (Postpartum). Jakarta: Trans Info Media, 2014.

[14] Budiati T., "Efektivitas Pemberian Paket 'Sukses ASI' terhadap Produksi ASI Ibu Menyusui dengan Seksio Sesarea di Wilayah Depok Jawa Barat," [Tesis]. Universitas Indonesia, 2009.

[15] H. Kusumaningtyas, Wara D. P. Rengga, and H. Suyitno, "Pengolahan Limbah Tanaman Pisang (Musa paradisiaca) menjadi Dendeng dan Abon Jantung Pisang sebagai Peluang Wirausaha Baru bagi Masyarakat Pedesaan," J. Penerapan Teknol. dan Pembelajaran, vol. 8, no. 2, 2010.

[16] E. Wahyuni, S. Sumiati, and N. Nurliani, "Pengaruh Konsumsi Jantung
Pisang Batu terhadap Peningkatan Produksi ASI di Wilayah Puskesmas Srikuncoro, Kecamatan Pondok Kelapa, Bengkulu Tengah Tahun 2012," Bul. Penelit. Sist. Kesehat., vol. 15, no. 4, 2013.

[17] Rilyani and R. Wulandasari, "Konsumsi Sayur Jantung Pisang terhadap Peningkatan Produksi ASI pada Ibu Masa Nifas," Holistik J. Kesehat., vol. 13, no. 4, 2019.

[18] Apriza, "Pengaruh Konsumsi Rebusan Jantung Pisang terhadap Ekskresi ASI pada Ibu Menyusui di Desa Kuapan Wilayah Kerja Puskesmas Tambang Tahun 2016," J. Ners Univ. Pahlawan Tuanku Tambusai, vol. 1, no. 1, 2017.

[19] S. Wulan and D. M. B. Girsang, "Pengaruh Jantung Pisang (Musa Paradisiaca L.) terhadap Produksi ASI," J. Ris. Hesti Medan Akper Kesdam I/BB Medan, vol. 5, no. 2, pp. 83-90, 2020.

[20] I. Permatasari and U. L. Qomar, "Penerapan Pemberian Olahan Jantung Pisang untuk Kelancaran Produksi ASI di PMB Siti Isti'anatul Amd., Keb.," Proceeding of The URECOL, pp. 398406, 2019.

[21] R. Haryono and S. Setianingsih, Manfaat ASI Eksklusif untuk Buah Hati Anda. Yogyakarta: Gosyen Publishing, 2014.

[22] H. Wiknjosastro, Ilmu Kebidanan. Jakarta: Yayasan Bina Pustaka Sarwono, 2009.

[23] I. P. Sari, "Daya Laktagogum Jamu Uyup-uyup dan Ekstrak Daun Katu (Sauropus androgynus Merr.) pada Glandula Ingluvica Merpati: Lactagogue effect of uyup-uyup (traditional medicine) and Sauropus androgynus Merr extract on pigeon inglu," Maj. Farm. Indones., vol. 14, no. 2015, 2015.

[24] Riani, "Pengaruh Konsumsi Rebusan Jantung Pisang terhadap Ekskresi ASI pada Ibu Menyusui di Desa Ranah Wilayah Kerja Puskesmas Kampar 
Tahun 2016," J. Ners, vol. 1, no. 1, 2017.

[25] M. J. Hockenberry and D. Wilson, "Essential of pediatric nursing," St. Louis Missoury Mosby, 2009.

[26] A. Pillitteri, Maternal \& child health nursing: care of the childbearing \& childrearing family. Lippincott Williams \& Wilkins, 2010.

[27] R. Noviawanti, L. Fitri, and I. I. Silalahi, "Jantung Pisang Terhadap Peningkatan Produksi ASI di Desa Sungai Putih Tahun 2018," Al-Insyirah Midwifery J. Ilmu Kebidanan (Journal Midwifery Sci., vol. 8, no. 2, pp. 83-88, 2019.
[28] H. Astuti, "Efektifitas Jantung Pisang Dan Daun Katuk Terhadap Produksi Asi Pada Ibu Menyusui Di Desa Teluk Kiambang Wilayah Kerja Puskesmas Tempuling Kecamatan Tempuling Kabupaten Indragiri Hilir," Selodang Mayang J. Ilm. Badan Perenc. Pembang. Drh. Kabupaten Indragiri Hilir, vol. 6, no. 1, pp. 15-22, 2020.

[29] H. Syarief, R. M. Damanik, T. Sinaga, and T. H. Doloksaribu, "Pemanfaatan Daun Bangun-bangun dalam Pengembangan Produk Makanan Tambahan Fungsional untuk Ibu Menyusui," J. Ilmu Pertan. Indones., vol. 19, no. 1, pp. 38-42, 2014. 